\title{
MEMBANGUN SISTEM PERIZINAN TERPADU BIDANG LINGKUNGAN HIDUP DI INDONESIA
}

\author{
Helmi \\ Fakultas Hukum Universitas J ambi
}

\begin{abstract}
Applicability of Law. 32 of 2009 on the Protection and Management of the Environment an integrated licensing increasingly strict environmental field. Nevertheless, there are still many problems to the implementation of an integrated licensing is the inconsistency of the sectoral rules, ego-sectoral technical agencies, the strong economic interests than the interests of environmental protectionand social welfare. Implementation of an integrated licensing system requires integration of the environmental field of governance, institutions, power, mechanisms and requirements to achieve sustainable environmental management. That requires the synchronization settings, the integration of sustainable development and institutional models of integrated environmental permit system.
\end{abstract}

Key words: environment, licensing system, integrated.

\begin{abstract}
Abstrak
Berlakunya UU No. 32 Tahun 2009 tentang Perlindungan dan Pengelolaan Lingkungan Hidup, perizinan terpadu bidang lingkungan hidup semakin tegas. Walaupun demikian, masih terdapat berbagai persoalan untuk penerapan perizinan terpadu tersebut yakni inkonsistensi berbagai peraturan sektoral, ego sektoral instansi teknis, kuatnya kepentingan ekonomi dibandingkan kepentingan pelestarian lingkungan dan kesejahteraan masyarakat. Penyelenggaraan sistem perizinan terpadu bidang lingkungan hidup membutuhkan keterpaduan sistem pengaturan, kelembagaan, kewenangan, mekanisme dan persyaratan untuk mewujudkan pengelolaan lingkungan hidup berkelanjutan. Untuk itu dibutuhkan sinkronisasi pengaturan, integrasi prinsip pembangunan berkelanjutan dan model kelembagaan sistem perizinan bidang lingkungan terpadu.
\end{abstract}

Kata kunci: lingkungan hidup, sistem perizinan, terpadu.

\section{Pendahuluan}

Cita-cita mewujudkan good governance dan clean goverment merupakan tuntutan fundamental bagi tatanan masyarakat global, maupun masyarakat lokal. ${ }^{1}$ Dalam negara hukum kesejahteraan yang dianut Indonesia, tugas utama pemerintah untuk mewujudkan tujuan negara salah satunya melalui pelayanan publik dan turut sertanya pemerintah dalam kehidupan sosial masyarakat. Salah satu otoritas pemerintah tersebut adalah penyelenggaraan sistem perizinan bidang lingkungan hidup.

Jawahir Thantowi, "Norma Hukum Pelayanan Publik", Jurnal Hukum, Vol. 14 No. 3, April 2004, Jakarta:

Fakultas Hukum Universitas Pancasila, hlm. 435.
Perizinan diistilahkan dengan lincence, permit (Inggris); vergunning (Belanda). Izin hanya merupakan otoritas dan monopoli pemerintah. Tidak ada lembaga lain di luar pemerintah yang bisa memberikan izin pengelolaan lingkungan.

Izin bidang lingkungan hidup merupakan alat pemerintah yang bersifat yuridis preventif, dan digunakan sebagai instrument administrasi untuk mengendalikan perilaku dalam rangka perlindungan dan pengelolaan lingkungan hidup. Perizinan sebagai wujud penerapan undang-undang lingkungan hidup, tentu harus dilakukan sesuai dengan undang-undang (selanjutnya penulis singkat menjadi UU) yakni ter- 
padu. ${ }^{2}$ Perizinan terpadu bidang lingkungan hidup tidak hanya tentang teknis administrasi (prosedur, syarat, waktu dan biaya), juga berkaitan dengan aspek subtansi perizinan bidang lingkungan hidup itu sendiri. Penyelenggaraan perizinan pada seluruh bidang lingkungan hidup, seperti kehutanan, pertambangan, perkebunan dan bidang-bidang lainya, harus didasarkan pada undang-undang lingkungan hidup sebagai payung.

Pengganti UU No. 23 Tahun 1997, pada Oktober 2009 diberlakukan UU No. 32 Tahun 2009 tentang Perlindungan dan Pengelolaan Lingkungan Hidup (UU-PPLH). Undang-undang ini mengendung beberapa inovasi dan perbaikan, antara lain berkaitan dengan ketentuan penyelesaian sengketa di luar pengadilan untuk masalah-masalah lingkungan, class action, ketentuan pembuktian (strict liability), penerapan hukum perdata, audit lingkungan, ketentuan daluwarsa (statue of limitation), sanksi administratif, kriminalisasi tindak pelanggaran lingkungan yang dilakukan oleh korporasi. ${ }^{3} \mathrm{Da}$ Iam UU ini, perizinan terpadu bidang lingkungan hidup semakin ditegaskan. Sesuai dengan makna lingkungan hidup dalam UU-PPLH (Pasal 1 angka 1 UU-PPLH), ruang lingkup lingkungan hidup mencakup seluruh sektor seperti kehutanan, pertambangan, perkebunan, industri, perikanan/ kelautan, dan lain-lain.

Konsekuensi makna dan ruang lingkup lingkungan hidup, izin bidang lingkungan hidup harus dilakukan secara terpadu. Ketentuan mengenai sistem perizinan dalam UU-PPLH diatur tentang keterkaitan hubungan antara izin lingkungan dengan izin usaha atau kegiatan (penulis menamakan keduanya dengan "izin bidang lingkungan hidup). Pasal 36-41 UU-PPLH mengatur tentang perizinan dimaksud. Setiap orang untuk memperoleh izin usaha atau kegiatan diharuskan memiliki Amdal atau UKL-UPL dan memiliki izin lingkungan. Untuk mendapat-

2 Lihat, Taufik Imam Santoso, "Amdal dan Upaya Penegakan Hukum Lingkungan", Jurnal Yustika, Vol. 10 No. 2, Desemser 2007, Padang: FH Unand, hlm. 3-4.

Eriyantouw Wahid, "Penegakan Hukum Lingkungan di Indonesia: Pilihan atas Instrumen Hukum Pidana", J urnal Hukum, Vol. 1 No. 1 April 2008, Jakarta: Fakultas Hukum Universitas Pancasila, hlm. 33 . kan izin lingkungan tersebut, juga diwajibkan adanya Amdal. J adi, Amdal dalam hal ini terdiri dari Amdal untuk mendapat izin lingkungan dan Amdal untuk mendapatkan izin usaha atau kegiatan.

Keterkaitan lain antara izin usaha atau kegiatan dengan izin lingkungan juga diatur dalam hal penyelenggaraan izin. Dalam UUPPLH, "dalam hal izin lingkungan dicabut, izin usaha dan/atau kegiatan dibatalkan (Pasal 40 ayat 1), dan dalam hal usaha dan/ atau kegiatan mengalami perubahan, penanggungj awab usaha dan/atau kegiatan wajib memperbaharui izin lingkungan. Sayangnya, selama belakunya kedua UU LH (No. 4 Tahun 1982 dan N0. 23 Tahun 1997), penyelenggaraan perizinan bidang lingkungan justru tidak terpadu.

Pembangunan sistem perizinan terpadu pada bidang lingkungan hidup merupakan tuntutan di tengah kepentingan meningkatkan investasi dan penurunan kualitas pelestarian fungsi lingkungan hidup. Kesalahan terjadi selama ini, pemerintah dan sebagian besar akademisi menyatakan bidang sumber daya alam bukanlah bagian lingkungan hidup. Hal tersebut berlanjut, karena bidang-bidang di atas diatur secara sektoral yakni UU Kehutanan, UU Perkebunan, UU Pertambangan, UU Perikanan. Lingkungan hidup juga diatur dalam UU sendiri. UU Sektoral mengesampingkan UU Lingkungan Hidup.

Izin usaha atau kegiatan dengan izin lingkungan ataupun Amdal seolah tidak ada hubungan sama sekali. Izin lingkungan "hanya" sebagai syarat mendapatkan izin usaha atau kegiatan. Jika izin sudah diperoleh, izin lingkungan menjadi dokumen "mati". Walaupun, perusahaan melanggar izin lingkungan, izin usaha dan/atau kegiatan tetap tidak dapat diganggu gugat. Padahal, izin usaha atau kegiatan dapat dibatalkan jika terbukti melanggar norma lingkungan hidup.

Berlakunya UU No. 32 Tahun 2009 juga menimbulkan polemik. Kalangan pengusaha bidang kehutanan dan pertambangan mencemaskan ketentuan perizinan yang dianggap akan menghambat produktivitas perusahaan. Perlu diingat di sini, bahwa perjalanan pembangunan 
kehutanan selama ini telah memberikan dampak positif bagi perekonomian nasional melalui kontribusinya dalam perolehan devisa dan kesempatan kerja. ${ }^{4}$ Menurut Sudi Fahmi, dalam bidang kehutanan sangat rentan terjadinya inkonsistensi huku, indikatornya adalah masih dijumpainya beberapa peraturan yang tidak sejalan dengan peraturan yang lain, dalam hal ini Sudi Fahmi memberikan contoh dalam hal perizinan. ${ }^{5}$ Sementara pemerintah, sampai saat ini belum mengeluarkan peraturan pelaksana UU ini. Persoalan semakin sulit, jika berhadapan dengan sistem peraturan perundang-undangan di Indonesia sebagaimana diatur UU No. 10 Tahun 2004 tentang Pembentukan Peraturan Perundang-Undangan. Dalam UU ini semua UU memiliki kedudukan yang sama, tidak ada yang lebih tinggi atau lebih rendah.

Pemerintah telah berupaya untuk mewujudkan sistem perizinan terpadu melalui pembentukan sistem Pelayanan Terpadu Satu Pintu (PTSP). Tujuan sistem ini untuk meningkatkan investasi di Indonesia. Ditinjau dari segi hukum lingkungan, secara substansi PTSP belum menjadikan UU-PPLH sebagai salah satu pedoman dalam pelayanan izin. PTSP baru terbatas pada upaya dari sisi administratif.

Berdasarkan uraian di atas, penulis tertarik untuk membahas mengenai makna dan hakikat perizinan terpadu bidang lingkungan hidup; dan upaya apa yang diakukan untuk membangun sistem perizinan terpadu bidang lingkungan hidup di Indonesia.

\section{Pembahasan}

\section{Makna dan Hakikat Perizinan Terpadu Bidang Lingkungan Hidup}

N.M. Spelt dan J.B.J.M. Ten Berge ${ }^{6}$ perizinan untuk istilah izin dalam arti luas, sedangkan izin dalam arti sempit disebut "izin"

4 Aswandi, dkk, "Pendekatan Holistik Penanggulangan IIlegal Logging dan Degradasi Hutan", J urnal Inovasi Vol. 4 No. 1, Maret 2007, hlm. 39.

5 Sudi Fahmi, "Problematika Hukum Dalam Bidang KehuTanan", J urnal Hukum Respublika, Vol. 6 No. 1 Tahun 2006, Pekanbaru: Fakultas Hukum Universitas Lancang Kuning, hlm. 47-50.

6 N.M. Spelt dan J.B.J.M. ten Berge, 1993, Pengantar Hukum Perizinan, disunting oleh Philipus M. Hadjon, Surabaya: Yuridika, hlm. 1-2. saja. Izin (dalam arti sempit) lebih lanjut dibedakan dengan bentuk-bentuk perizinan lainnya seperti dispensasi, konsesi, rekomendasi, tanda daftar, surat persetujuan, dan pendaftaran.

Izin dalam arti luas (perizinan) ialah suatu persetujuan dari penguasa berdasarkan undang-undang atau peraturan pemerintah, untuk dalam keadaan tertentu menyimpang dari ketentuan-ketentuan larangan perundangan". ${ }^{7}$ Sjachran Basah dikutip I Made Arya Utama, menyatakan, izin sebagai perbuatan Hukum Administrasi bersegi satu yang mengaplikasikan peraturan dalam hal konkreto berdasarkan persyaratan dan prosedur yang ditetapkan dalam peraturan perundang-undangan yang berlaku. ${ }^{8}$ Berdasarkan pendapat tersebut, izin bidang lingkungan hidup adalah persetujuan yang dikeluarkan oleh pemerintah dalam rangka pengelolaan lingkungan hidup.

Pada mulanya pengelolaan lingkungan hidup dilakukan melalui paradigma kekuasaan sektoral masing-masing instansi. ${ }^{9}$ Selanjutnya tidak koordinatif dan tidak terpadu, dengan penundukan kepada sistem hukum yang bersifat sektoral dan tidak menyeluruh (comprehensive law) pula. Pendekatan ini tidak tepat, karena sifat dan hakikat lingkungan hidup adalah menyeluruh dan satu dengan lainnya, saling terhubung sesuai dengan asas lingkungan itu sendiri, "everything is connected to everything else", begitu pula dengan sifat mobile atau geraknya, "everything must go somewhere".

Berdasarkan pemikiran tersebut, perlu dasar hukum yang terpadu untuk seluruh pengelolaan lingkungan hidup. Oleh karena itu, agar semua sektor dan unit instansional yang berkompeten mengelola lingkungan, hendaknya didasarkan kepada prinsip keterpaduan serta

\footnotetext{
Loc. cit.

Lihat Lies Ariany, "Telaah Dalam Bidang Kehutanan di Indonesia Ditinjau Dari Hukum Administrasi Negara", J urnal IImu Hukum Syiar Madani, Edisi Mei 2008, Bandung: Fakultas Hukum Universitas Islam Bandung, hlm. 73.

9 Rizal Muchtasar, "Strategi Pengelolaan Lingkungan $\mathrm{Hi}$ dup Dalam Usaha Pertambangan", Jurnal IImiah Unhalu, Edisi, Oktober 2010, Kendari: Univ. Haluoleo, hlm 5 .
} 
koordinasi, sehingga tidak bersifat sektoral, namun terpadu dan terkoordinasi.

Berdasar Pasal 1 angka 2 UU-PPLH, "perlindungan dan pengelolaan lingkungan hidup adalah upaya sistematis dan terpadu yang dilakukan untuk melestarikan fungsi lingkungan hidup dan mencegah terjadinya pencemaran dan/ atau kerusakan lingkungan hidup yang meliputi perencanaan, pemanfaatan, pengendalian, pemeliharaan, pengawasan, dan penegakan hukum. Mencermati konsep tersebut, ruang lingkup perlindungan dan pengelolaan lingdungan hidup tidak hanya terbatas pada persoalan polusi, pencemaran saja, namun juga terkait dengan pengelolaan sumber daya alam seperti kehutanan, pertambangan dan kehutanan. Hal ini tentu berkonsekuensi pada ruang lingkup sistem perizinan bidang lingkungan hidup. Terkait dengan aspek substansi, perizinan terpadu bidang lingkungan hidup merupakan suatu sistem perizinan yang mencakup seluruh aktivitas perencanaan, pemanfaatan dan pemeliharaan ruang beserta isinya.

Perizinan terpadu bidang lingkungan hidup berkaitan dengan aspek substansinya yaitu sesuai dengan makna lingkungan hidup, maupun aspek administrasi yaitu mekanisme, persyaratan, waktu dan biaya. Selain itu, perizinan terpadu bidang lingkungan hidup sebagai suatu sistem, berdasarkan UU-PPLH perizinan lingkungan hidup harus didasarkan pada Kajian Lingkungan Hidup Strategis (KLHS), rencana tata ruang, baku mutu lingkungan hidup, kriteria baku kerusakan lingkungan hidup, dan Analisis Mengenai Dampak Lingkungan (AMDAL). KLHS merupakan instrumen yang baru dan sangat penting dalam kaitannya dengan penyelenggaraan sistem perizinan lingkungan hidup.

\section{Membangun Sistem Perizinan Terpadu Bidang Lingkungan Hidup}

Pembangunan sistem perizinan terpadu apalagi bidang lingkungan hidup, tidak cukup hanya menyatukan dan menyederhanakan prosedur, mempermudah syarat, menyingkat waktu dan memperkecil biaya mengurus izin. Berikut ini penulis bahas mengenai hal-hal yang perlu dilakukan dalam upaya membangun sistem perizinan terpadu di bidang lingkungan hidup.

\section{Sinkronisasi Peraturan Perundang-Undangan Sistem Perizinan Bidang Lingkungan Hidup di Indonesia}

Pemberlakuan UU-PPLH, menimbulkan implikasi hukum bagi sistem perizinan di Indonesia. Semua peraturan perundang-undangan bidang lingkungan hidup tidak boleh bertentangan dengan UU-PPLH sebagai norma hukum "payung atau pedoman". UU No 32 Tahun 2009 sebagai alat penertib, penjaga keseimbangan dan katalisator pembangunan. UU-PPLH seharusnya merupakan terobosan bagi keberlangsungan dan kelestarian lingkungan untuk mewujudkan pembangunan berkelanjutan di Indonesia.

Berdasarkan konsep sistem keterpaduan perizinan bidang lingkungan hidup, seluruh peraturan perundang-undangan bidang lingkungan hidup seharusnya sinkron. Hal ini merupakan langkah utama menuju sistem perizinan terpadu bidang lingkungan hidup di Indonesia. Namun saat ini, justeru sebaliknya. Perizinan pada masing-masing sektor seperti kehutanan, perkebunan dan pertambangan diatur oleh UU tersendiri. Selain persoalan substansi sistem perizinan, pengaturan masing-masing sektor dalam UU tersendiri makin menumbuhkan sikap "ego sektoral" dalam penyelenggaraan perizinan.

Undang-undang di Indonesia, cenderung bersifat sektoral karena draft RUU datang dari kementerian masing-masing. Akibatnya undangundang Kehutanan adalah milik kementerian Kehutanan. Undang-undang Pertambangan milik kementerian pertambangan. Undang-undang Lingkungan Hidup milik kementerian Lingkungan Hidup, dan seterusnya. Pelaksanaan terjadi tumpang tindih dan saling menangmenangan. Keinginan sinergis jauh dari jangkauan, pengelolaan sumberdaya alam menunjukkan menang kalah. ${ }^{10}$ Masing-masing pihak

10 Otong Rosadi, "Pengelolaan Sumberdaya Alam: Best regard, Cita Hukum, Politik Hukum dan Realita", J urnal Mahkamah, Tahun 2008, Pekanbaru: UIR, hlm. 1. 
merasa memiliki otoritas penuh menyelenggarakan perizinan, tanpa harus berkoordinasi.

Ketaatan pengaturan bidang-bidang sektoral, ruang lingkup pemberlakuan pengaturan bidang-bidang sektoral seharusnya menjadi bagian UU-PPLH. Persoalannya, UU-PPLH berhadapan dengan pengaturan yang setingkat yakni UU Kehutanan, UU Perkebunan dan UU Pertambangan serta sektor-sektor lain yang juga diatur dengan UU. Bahkan bidang pertambangan sendiri terdapat 3 (tiga) bidang yang masing-masing diatur oleh UU sendiri.

Berdasarkan UUD 1945, "setiap rancangan undang-undang dibahas oleh Dewan Perwakilan Rakyat dan Presiden untuk mencapat persetujuan bersama (Pasal 20 ayat 2). Presiden mengesahkan rancangan undangundang yang telah disetujui bersama untuk menjadi undang-undang (Pasal 20 ayat 3). Jadi antara UU yang satu tidak lebih tinggi terhadap UU lainnya.

Berdasarkan UU No. 10 Tahun 2004 tentang Pembentukan Peraturan Perundang-undangan, hierarki peraturan perudang-undangan adalah (Pasal 7 ayat 1): Undang-undang Dasar Negara Republik Indonesia Tahun 1945; Undang-undang/ Peraturan Pemerintah Pengganti Undang-Undang; Peraturan Pemerintah; Peraturan Presiden; Peraturan Daerah. ${ }^{11}$

Materi muatan yang harus diatur dengan Undang-undang berisi hal-hal sebagai berikut. Pertama, mengatar lebih lanjut ketentuan Undang-undang Dasar Negara Republik Indonesia Tahun 1945 yang meliputi: hak-hak asasi manusia; hak dan kewajiban warga negara; pelaksanaan dan penegakan kedaulatan negara serta pembagian kekuasaan negara; wilayah negara dan pembagian daerah; kewarganegaraan dan kependudukan; dan keuangan negara. Kedua, diperintahkan oleh suatu Undang-undang untak diatur dengan Undang-undang (Pasal 8).

11 Pasal 7 ayat (2), peraturan daerah terdiri dari Peraturan Daerah Provinsi, Peraturan Daerah Kabupaten/ Kota dan Peraturan Desa. Kemudian ayat 3 Pasal ini menambah "J enis Peraturan Perundang-undangan selain sebagaimana dimaksud pada ayat (1), diakui keberadaannya dan mempunyai kekuatan hukum mengikat sepanjang diperintahkan oleh Peraturan Perundang-undangan yang lebih tinggi".
Menurut Hans Kelsen, norma dasar dari suatu tatanan hukum positif tidak lain adalah peraturan fundamental tentang pembuatan berbagai norma dari tatanan hukum positif itu. ${ }^{12}$ Norma dasar menurut Kelsen adalah sumber hukum, artinya menentukan validitas dan efektivitas hukum, seperti UU. Kelsen juga mengatakan, setiap norma hukum "yang lebih tinggi" adalah "sumber" dari norma hukum yang lebih rendah. ${ }^{13} \mathrm{Hal}$ ini berarti bahwa peraturan lebih rendah harus didasarkan pada peraturan lebih tinggi, sampai pada norma dasar (fundamental). Sebagaimana lebih lanjut dikatakan oleh Kelsen, ${ }^{14}$ pembentukan norma hukum biasanya merupakan penerapan norma hukum yang lebih tinggi, yang mengatur pembentukannya, dan penerapan norma hukum yang lebih tinggi biasanya merupakan pembentukan norma hukum yang lebih rendah yang ditentukan oleh norma hukum yang lebih tinggi tersebut.

Pendapat Hans Kelsen tersebut apabila direflesikan pada UU No. 32 Tahun 2009 sebagai ketentuan pokok terhadap UU sektoral lainnya, terdapat dua makna. Makna pertama, dari sisi substansi, UU Kehutanan, Perkebunan dan UU Bidang Pertambangan sebenarnya termasuk segi-segi lingkungan hidup yang diatur oleh UU-PPLH, karena ruang lingkup UU-PPLH meliputi ruang, tempat Negara Kesatuan Republik Indonesia yang ber-Wawasan Nusantara dalam melaksanakan kedaulatan, hak berdaulat, dan yurisdiksinya. Oleh karena itu, UUPPLH secara substansi mempunyai kedudukan yang lebih tinggi dibandingkan dengan undangundang Kehutanan, undang-undang Perkebunan dan UU bidang Pertambangan.

Kedua, secara formil kedudukan masingmasing undang-undang tersebut sederajat, jadi satu sama lain tidak lebih tinggi. Seperti yang terdapat UUD 1945 dan Undang-undang No. 10 Tahun 2004, semua undang-undang merupakan produk bersama antara DPR dan Pre-

\footnotetext{
12 Hans Kelsen, 2006, Teori Umum tentang Hukum dan Negara, Bandung: Nusamedia dan Nuansa, hlm. 164, terjemahan dari Hans Kelsen, 1971, General Theory of Law and State, New York: Russel and Russel.

13 Ibid., hlm. 188.

14 Ibid, hlm. 191.
} 
siden. Oleh karena itu, UU-PPLH tidak lebih tinggi terhadap undang-undang Kehutanan, Perkebunan maupun undang-undang bidang Pertambangan. Namun demikian, pada tataran praktik, masing-masing sektor membentuk peraturan pelaksana dan mengabaikan undangundang lingkungan hidup. Kementerian sektoral merasa memiliki kekuatan hukum yang sama dan dapat melaksanakan wewenangnya sesuai dengan ketentuan UU pada masingmasing sektor. Hal inilah yang terjadi pada penyelenggaraan sistem perizinan bidang lingkungan hidup di Indonesia. Berdasarkan uraian di atas, norma pengaturan yang terdapat pada UU-PPLH merupakan norma hukum lingkungan, secara substansi dan administrasi (formil) seharusnya pengaturan bidang-bidang sektoral tersebut merupakan bentuk peraturan lebih Ianjut dari UU-PPLH.

Beberapa kementerian terkait yang dikoordinasi Kementerian Bidang Perekonomian pada 2010 telah melaksanakan sinkronisasi berbagai Undang-Undang terkait pemberlakuan UU-PPLH. Kekhawatiran dari proses tersebut, UU-PPLH kembali "kalah kuat" oleh kepentingan ekonomi sektor kehutanan, perkebunan dan pertambangan. ${ }^{15}$ Secara konseptual, sinkronisasi pengaturan perizinan bidang lingkungan hidup harus didasarkan pada makna lingkungan dan amanat keterpaduan dalam UU-PPLH. Pasal 126 UU-PPLH dapat dijadikan sebagai pintu masuk melakukan sinkronisasi, "Peraturan pelaksanaan yang diamanatkan dalam UndangUndang ini ditetapkan paling lama 1 (satu) tahun terhitung sejak Undang-Undang ini diberlakukan". Terhitung 4 Oktober 2010 seluruh peraturan pelaksana UUPPLH "seharusnya" diterbitkan. Namun, sampai saat ini (akhir tahun 2010) belum satupun peraturan pelaksana baik peraturan pemerintah maupun peraturan menteri yang diberlakukan.

15 BKPM menargetkan peningkatan investasi yang masuk ke Indonesia pada 2010 meningkat sekitar 10-15\% dari tahun Ialu. Adapun investasi yang masuk ke Indonesia selama 2009 mencapai Rp 135 triliun. Sementara target tersebut jelas terkait dengan sumberdaya lingkungan hidup. Tampaknya BKPM sendiri kurang memperhitungkan kepentingan pelestarian fungsi lingkungan hidup.
Berdasarkan hal tersebut, apabila dihubungkan dengan maksud sinkronisasi, maka pembentukan peraturan pemerintah dan peraturan menteri yang diamanatkan oleh UUPPLH bisa dijadikan sebagai ruang bagi pemerintah untuk melakukan pengaturan sistem perizinan terpadu bidang lingkungan hidup di Indonesia. Sistem perizinan masuk dalam materi PP tentang pencegahan (Pasal 56), akan semakin mudah mewujudkan sistem perizinan terpadu bidang lingkungan hidup.

Berdasarkan ruang lingkup sistem perizinan terpadu bidang lingkungan hidup, dalam PP tersebut harus mencakup perizinan bidangbidang sektor lingkungan hidup. Pertama, tidak hanya mengatur tentang izin lingkungan, tapi juga mencakup perizinan bidang kehutanan, perkebunan, pertambangan dan perikanan/kelautan serta seluruh perizinan bidang lingkungan hidup lainnya. Kedua, pengaturan sistem perizinan terpadu perlu menghindari "over proteksi" tersebut. Keseimbangan antara kepentingan ekonomi, lingkungan hidup dan sosial akan menjadikan pengaturan sistem perizinan terpadu sebagai instrumen mewujudkan pembangunan berkelanjutan sesuai dengan ketentuan Pasal 44 UU-PPLH yang menentukan bahwa

Setiap penyusunan peraturan perundang-undangan pada tingkat nasional dan daerah wajib memperhatikan perlindungan fungsi lingkungan hidup dan prinsip perlindungan dan pengelolaan lingkungan hidup sesuai dengan ketentuan yang diatur dalam Undang-Undang ini.

Pasal 6, khususnya ayat (2) UU No. 10 Tahun 2004 menegaskan bahwa asas keterpaduan dalam rangka penyusunan peraturan perundang-undangan berbasis lingkungan hidup merupakan "keniscayaan". Sinkronisasi peraturan perudang-undangan berbasis lingkungan hidup dalam sistem perizinan terpadu bidang lingkungan hidup, bukan berarti mengutamakan kepentingan pelestarian. J usteru dalam konteks pembangunan berkelanjutan patut dihindari, karena akan menciptakan "stagnasi" proses pembangunan di Indonesia. 
Ketiga, sonkronisasi untuk mewujudkan sistem hukum perizinan terpadu bidang lingkungan hidup harus dijiwai oleh prinsip-prinsip pembangunan berkelanjutan. Prinsip-prinsip pembangunan berkelanjutan dijadikan sebagai dasar substansi pengaturan sistem perizinan terpadu bidang lingkungan hidup. Adapun prinsip-prinsip tersebut adalah Prinsip keadilan antargenerasi (Intergenerational Equity), Prinsip keadilan dalam satu generasi (Intragenerational Equity), Prinsip pencegahan dini (Precautionary Principle), Prinsip perlindungan keanekaragaman hayati (Biodiversity Conservation), Prinsip internalisasi biaya lingkungan.

Pengaturan pembangunan berwawasan lingkungan belum berjalan secara optimal sebagaimana yang diharapkan. Upaya untuk mewujudkan hal tersebut harus dilakukan oleh berbagai pihak antara lain dengan mendorong semua pihak, baik pemerintah maupun masyarakat agar berperan secara aktif dan mandiri dalam pembangunan lingkungan, dengan mendasarkan pada paham bahwa manusia perlu ditingkatkan posisinya, dari perusak lingkungan menjadi penyelamat lingkungan, pencinta lingkungan dan pengaman lingkungan. ${ }^{16}$ Pengintegrasian prinsip-prinsip pembangunan berkelanjutan dalam aktivitas perizinan di Indonesia, secara tersirat diatur dalam UUD 1945. Menurut J imly Asshiddiqie, ${ }^{17}$ Pasal 33 ayat (4) UUD 1945 menegaskan adanya prinsip keberlanjutan yang terkandung dalam demokrasi ekonomi, "perekonomian nasional diselenggarakan berdasar atas demokrasi ekonomi dengan prinsip berkelanjutan, berwawasan lingkungan.

Integrasi prinsip-prinsip pembangunan berkelanjutan ke dalam sistem perizinan bidang lingkungan hidup, diharapkan dapat memenuhi kebutuhan masa sekarang dan tidak mengancam kelestarian fungsi lingkungan hidup untuk kebutuhan generasi yang akan datang. Untuk mewujudkan prinsip tersebut, maka prin-

16 Yoni Hermawan, "Partisipasi Masyarakat Nelayan dalam Pengelolaan Lingkungan Hidup", Jurnal Bumi Lestari, Vol. 7 No. 2, Agustus 2007, Denpasar: PPLH Universitas Udayana, hlm. 179

17 Jimly Asshiddiqie, 2009, Green Consitutiton: Nuansa Hijau UUD Negara Republik Indonesia Tahun 1945, Jakarta: Raj awali Pers, hlm. 133. sip pencegahan dini, prinsip keanekaragaman hayati dan internalisasi biaya lingkungan harus dilakukan terlebih dahulu.

Berdasarkan pasal-pasal dalam UU-PPLH, secara keseluruhan prinsip-prinsip pembangunan berkelanjutan sudah ada yakni melalui KLHS. KLHS sebagai instrumen untuk mewujudkan prinsip-prinsip pembangunan berkelanjutan. Pasal 1 angka 10 UU-PPLH, yakni:

Kajian lingkungan hidup strategis, yang selanjutnya disingkat KLHS, adalah rangkaian analisis yang sistematis, menyeluruh, dan partisipatif untuk memastikan bahwa prinsip pembangunan berkelanjutan telah menjadi dasar dan terintegrasi dalam pembangunan suatu wilayah dan/atau kebijakan, rencana, dan/ atau program."

Integrasi prinsip-prinsip pembangunan berkelanjutan dalam UU-PPLH, dilakukan meIalui KLHS. KLHS sebagai instrument pencegahan pencemaran atau kerusakan lingkungan hidup, merupakan wujud integrasi prinsipprinsip pembangunan berkelanjutan. Selanjutnya KLHS sebagai pedoman dan dituangkan dalam rencana pembangunan jangka panjang, jangka menengah, rencana tata ruang. Integrasi tersebut dituangkan dalam pengaturan dan penyelenggaraan sistem perizinan. KLHS pada akhirnya diwujudkan dalam pengambilan keputusan tentang izin bidang lingkungan hidup.

\section{Membangunan Sistem Perizinan Terpadu Bi- dang Lingkungan Hidup di Indonesia}

Pemberian izin dan pencabutan izin, bukanlah suatu tugas dan pekerjaan yang sederhana bagi pemerintah, karena itu pengeluaran izin harus mendapat kajian yang serius bagi pihak yang mengeluarkannya, baik itu dimaksudkan untuk mengendalikan atau mendistribusikannya, tentu dengan kriteria-kriteria yang jelas. Oleh karena itu, izin mempunyai konsekuensi yuridis yaitu membolehkan sesuatu yang pada mulanya dilarang baik itu oleh budaya, adat istiadat setempat maupun oleh hukum po- 
sitif bahkan oleh agama. ${ }^{18}$

Perizinan terpadu bidang lingkungan hidup dalam hal ini dikelompokkan menjadi dua macam, yakni pertama, keterpaduan dalam satu sektor bidang lingkungan, misalnya, izin sektor kehutanan, sektor perkebunan atau sektor pertambangan. Kedua, keterpaduan antar sektor lingkungan hidup. Maksudnya hubungan antar sektor lingkungan hidup, misalnya, izin sektor kehutanan terhadap sektor perkebunan, atau izin sektor kehutanan terhadap sektor pertambangan.

Sistem perizinan sesuai dengan UU-PPLH dikaitkan dengan keharusan memiliki Amdal. Untuk mendapatkan izin usaha atau kegiatan atau izin lingkungan disyaratkan memperoleh Amdal dari pejabat yang berwenang. Bagi izin yang tidak perlu Amdal, diharuskan memiliki UKL-UPL. Untuk mendapatkan Amdal, UKL-UPL juga diharuskan menempuh sejumlah prosedur, memenuhi persyaratan dan membayar biaya yang telah ditentukan oleh pejabat yang berwenang.

Perizinan dikaitkan pula beberapa kewajiban yang harus dilakukan oleh pengusaha atau penanggungj awab usaha sebelum dokumen izinnya dikeluarkan oleh pejabat yang berwenang. Pada saat izin telah diterbitkan, dibebankan kewajiban dan persyaratan untuk dilaksanakan oleh perusahaan, ini merupakan instrumen pengendali untuk ketaatan terhadap norma-norma lingkungan.

Sistem perizinan di Indonesia sebelum terbitnya UU-PPLH, lebih bersifat fragmented scheme, yakni izin yang satu seolah tidak terkait dengan izin lainnya. Misalnya, jika salah satu izin sudah dilanggar oleh suatu perusahaan maka izin lainnya masih dapat dijadikan alat untuk menjalankan aktivitas perusahaan. Suatu perusahaan pertambangan yang dinyatakan oleh pejabat yang berwenang telah melanggar izin pengelolaan limbah, namun masih tetap melakukan aktivitas berdasarkan izin atau kuasa pertambangan yang dimiliki.

18 Elita Rahmi, "Perizinan dalam Pemerintahan (sebuah Tantangan dan Harapan di Era Otonomi)", Jurnal Hukum Respublika, Vol. 4 No. 1, Tahun 2004, Pekanbaru: Fakultas Hukum Universitas Lancang Kuning, hlm. 122.
Berlakunya UU-PPLH, selain penyatuan berbagai izin lingkungan, juga hubungan antara izin lingkungan dan izin usaha atau kegiatan telah dipertegas. Dalam UU-PPLH, izin lingkungan merupakan syarat mendapatkan izin usaha atau kegiatan. Jika suatu perusahaan melanggar izin lingkungan misalnya tidak melakukan reklamasi pasca penambangan, mencemarkan lingkungan, maka izin lingkungan akan dicabut, karena perusahaan tersebut dinyatakan melanggar izin lingkungan. Pencabutan izin lingkungan mengakibatkan izin usaha atau kegiatan dibatalkan (Pasal 40 ayat 2). J ika izin lingkungan mengalami perubahan, penanggung jawab usaha atau kegiatan wajib memperbaharui izin lingkungan (Pasal 40 ayat 3).

Berdasarkan hal tersebut, dapat dikatakan, sistem perizinan yang terdapat pada UUPPLH, baru terbatas pada ketegasan mengenai izin lingkungan dan hubungannya dengan izin usaha atau kegiatan. Itupun masih menimbulkan persoalannya yakni syarat amdal untuk mendapatkan izin lingkungan dan posisi izin lingkungan itu sendiri. Amdal juga disyaratkan untuk mendapatkan izin usaha atau kegiatan. Setiap pelaku usaha bidang lingkungan hidup diharuskan memiliki 2 (dua) jenis amdal yakni amdal sebagai syarat mendapatkan izin lingkungan dan amdal untuk mendapatkan izin usaha atau kegiatan. Izin lingkungan sendiri merupakan syarat untuk mendapatkan izin usaha atau kegiatan.

Konsepsi di atas menimbulkan kerancuan apabila dilihat dari sisi keterpaduan. Izin lingkungan dan izin usaha atau kegiatan sebenarnya merupakan satu kesatuan dalam suatu rencana usaha atau kegiatan. Untuk melakukan usaha atau kegiatan, dalam amdal telah ditentukan persyaratan-persyaratan. Termasuk melaksanakan aktivitas seperti dalam izin lingkungan misalnya perencanaan, pengolahan, pemanfaatan atau pembuangan limbah ke media lingkungan. Kajian amdal juga termasuk tentang tingkat kebisingan, baku mutu lingkungan, dan lain-lain. Pengaturan mengenai izin lingkungan dalam UU-PPLH disyaratkan adanya amdal, hal ini menimbulkan ketidak- 
terpaduan dalam sistem perizinan bidang lingkungan.

Menurut penulis, amdal sudah cukup dijadikan sebagai syarat untuk mendapatkan izin usaha atau kegiatan, jadi tidak perlu izin lingkungan. Aktivitas dalam izin lingkungan, merupakan kewajiban yang harus dilakukan oleh penanggungjawab usaha atau kegiatan dalam rangka melaksanakan izin usaha atau kegiatannya. Aktivitas tersebut merupakan satu kesatuan yang harus dilakukan dalam melaksanakan izin usaha atau kegiatan, maka tidak diperlukan izin untuk melakukannya, misalnya, aktivitas untuk pengelolaan limbah maka dibutuhkan instalasi pengelolaan limbah (IPAL), jadi aktivitas membuang limbahnya sendiri tidak perlu izin.

Kekuasaan memberikan izin usaha atau kegiatan saat ini berada pada masing-masing sektor. Kementerian kehutanan mengeluarkan izin-izin bidang kehutanan, perkebunan oleh Kementerian Pertanian, Kementerian ESDM untuk izin usaha pertambangan. Untuk itu perizinan terpadu bidang lingkungan hidup perlu segera diwujudkan.

Sistem perizinan dengan PTSP, berdasarkan Perpres No. 27 Tahun 2009 dapat dijadikan sebagai modal sistem perizinan dimasa yang akan datang. Namun, seperti telah dikemukakan, PTSP masih mengandung beberapa kelemahan. Pertama, bentuk pengaturan dalam peraturan presiden (Perpres) tidak cukup kuat. Karena pengaturan perizinan sektorsektor lingkungan hidup lebih kuat yakni UU dan PP. Akibatnya, PTSP tergantung pada "toleransi" instansi sektoral, bukan ketaatan hukum instansi-instansi sektoral tersebut. Kedua, PTSP sekedar menyatukan sistem administrasi perizinan. Tujuan utamanya adalah penanaman modal sebanyak-banyaknya di Indonesia baik dalam negeri maupun luar negeri. Jadi pendapatan merupakan tujuan utama penerapan sistem PTSP. ${ }^{19}$

19 Kusnadi Wirasaputra, et., all, 2009, Biofuel; a Trap "Biofuel Sebuah Jebakan", Setara Foundation, Walhi Sum-Sel, Elang Hijau, Sawit Wacht, Misereor, Jambi, September 2009, hlm. 52.
Penerapan sistem PTSP sepenuhnya pada sistem perizinan bidang lingkungan hidup saat ini masih akan mengalami kendala ego sektoral dari masing-masing instansi teknis. Karena, pemberlakuan PTSP sepenuhnya akan mengakibatkan kehilangan wewenang instansi teknis dalam penerbitan perizinan.

Egosektoral yang terkait dengan kewenangan dapat diatasi dengan cara penerapan PTSP didasarkan pada lingkup sektoral. Pada bidang lingkungan hidup, dibentuk PTSP perizinan bidang lingkungan hidup yang mencakup sektor kehutanan, perkebunan dan pertambangan. Secara kelembagaan PTSP yang telah mengintegrasikan prinsip-prinsip pembangunan berkelanjutan dilaksanakan oleh masing-masing sektor.

Pembangunan sistem perizinan terpadu bidang lingkungan hidup tidak sekedar menyatukan pengaturan, membentuk kelembagaan (administratif), namun juga harus mengintegrasikan prinsip-prinsip pembangunan berlanjutan. Jadi langkah-langkah tersebut harus diikuti dengan perubahan dari sisi subtansi. Perubahan substansi dimaksudkan adalah, penyatuan sistem perizinan dalam perizinan terpadu bidang lingkungan hidup. Sistem terpadu ini didasarkan pada makna dan ruang lingkup lingkungan hidup yang mencakup seluruh bidang lingkungan hidup seperti kehutanan, perkebunan, pertambangan dan bidang lingkungan hidup lainnya.

\section{Penutup}

Simpulan

Pembangunan sistem perizinan terpadu bidang lingkungan hidup maka perlu dilakukan beberapa hal yaitu: pertama, sinkronisasi peraturan perundang-undangan sistem perizinan bidang lingkungan hidup. Sinkronisasi dimaksud didasarkan pada peraturan perundangundangan berbasis lingkungan hidup yang telah diamanatkan oleh UU-PPLH dengan mengintegrasikan prinsip-prinsip pembangunan berkelanjutan. Kedua, penguatan bentuk pengaturan dan pemilihan model PTSP sebagai sistem perizinan bidang lingkungan hidup untuk dapat mengatasi kendala ego sektoral. 


\section{Saran}

Penulis dalam hal ini memberikan saran yaitu: pertama, dibentuk PP perizinan terpadu bidang lingkungan hidup yang mencakup seluruh izin bidang lingkungan hidup; kedua, sistem perizinan terpadu bidang lingkungan hidup berada dalam satu lembaga perizinan yang melaksanakan tugas-tugas perizinan, yakni mengatur, mengeluarkan izin, melakukan koordinasi dan pengawasan penyelenggaraan izin bidang lingkungan hidup.

\section{Daftar Pustaka}

Ariany, Lies. "Telaah Dalam Bidang Kehutanan di Indonesia Ditinjau Dari Hukum Administrasi Negara". Jurnal IImu Hukum Syiar Madani. Edisi Mei 2008. Bandung: Fakultas Hukum Universitas Islam Bandung;

Asshiddiqie, Jimly. 2009. Green Consitutiton: Nuansa Hijau UUD Negara Republik Indonesia Tahun 1945. Jakarta: Rajawali Pers ;

Aswandi. dkk. "Pendekatan Holistik Penanggulangan Illegal Logging dan Degradasi Hutan". Jurnal Inovasi. Vol. 4 No. 1. Maret 2007;

Hermawan, Yoni. "Partisipasi Masyarakat Nelayan dalam Pengelolaan Lingkungan $\mathrm{Hi}$ dup". J urnal Bumi Lestari. Vol. 7 No. 2. Agustus 2007. Denpasar: PPLH Universitas Udayana;

Fahmi, Sudi. "Problematika hukum dalam bidang kehutanan". Jurnal Hukum Respublika. Vol. 6 No. 1. Tahun 2006. Pekanbaru: Fakultas Hukum Universitas Lancang Kuning;
Kelsen, Hans. 2006, Teori Umum tentang Hukum dan Negara, Bandung: Nusamedia dan Nuansa;

Muchtasar, Rizal. "Strategi Pengelolaan Lingkungan Hidup Dalam Usaha Pertambangan". Jurnal IImiah Unhalu. Edisi Oktober 2010. Kendari: PPLH Universitas Haluoleo;

Rahmi, Elita. "Perizinan dalam Pemerintahan (sebuah Tantangan dan Harapan di Era Otonomi)", Jurnal Hukum Respublika. Vol. 4 No. 1. Tahun 2004. Pekanbaru: Fakultas Hukum Universitas Lancang Kuning;

Rosadi, Otong. "Pengelolaan Sumberdaya Alam: Best regard, Cita Hukum, Politik Hukum dan Realita", Jurnal Mahkamah. Tahun 2008. Pekanbaru : Univ. Islam Riau;

Santoso, Taufik Imam. "Amdal dan Upaya Penegakan Hukum Lingkungan", J urnal Yustika. Vol.10 No. 2. Desemser 2007. Padang: FH Unand;

Spelt, NM. dan JBJ M ten Berge. 1993. Pengantar Hukum Perizinan. Philipus M. Hadjon (ed). Surabaya: Yuridika;

Thantowi, Jawahir. "Norma Hukum Pelayanan Publik". Jurnal Hukum. Vol. 14 No. 3. April 2004. J akarta: Fakultas Hukum Universitas Pancasila;

Wahid, Eriyantouw. "Penegakan Hukum Lingkungan di Indonesia: Pilihan atas Instrumen Hukum Pidana". Jurnal Hukum. Vol. 1 No. 1. April 2008. J akarta: Fakultas Hukum Universitas Pancasila;

Wirasaputra, Kusnadi. et. All. 2009. Biofuel; a Trap "Biofuel Sebuah Jebakan". Setara Foundation, Walhi SumSel, Elang Hijau, Sawit Wacht, Misereor, Jambi, September 2009. 